\title{
Cytogenetic analysis of three catfish species of the family Pseudopimelodidae (Teleostei, Siluriformes)
}

\author{
Emanuel Ricardo Monteiro Martinez ${ }^{1}$, Mauro Nirchio ${ }^{2}$, Angel Granado ${ }^{3}$, Fausto Foresti ${ }^{1}$ \\ and Claudio Oliveira ${ }^{1}$ \\ ${ }^{I}$ Departamento de Morfologia, Instituto de Biociências, \\ Universidade Estadual Paulista 'Julio de Mesquita Filho', Botucatu, SP, Brazil. \\ ${ }^{2}$ Escuela de Ciencias Aplicadas del Mar, Universidad de Oriente, Isla de Margarita, Venezuela. \\ ${ }^{3}$ Instituto Limnológico, Universidad de Oriente, Caicara del Orinoco, Bolivar, Venezuela.
}

\begin{abstract}
Cytogenetic analyses performed in Cephalosilurus apurensis, Microglanis aff. cottoides and Pseudopimelodus bufonius revealed that the three species have $2 n=54$ chromosomes: $C$. apurensis presented six metacentric (M), 28 submetacentric (SM), 14 subtelolocentric (ST), and six acrocentric (A) chromosomes, while $M$. aff. cottoides showed 10M, 32SM, 10ST and 2A, and $P$. bufonius had 12M, 30SM and 12ST. The nucleolus organizer regions (NORs) were present on the short arm of a middle-sized ST pair, identified as pair 19, in $C$. apurensis NORs were found on the short arm of a middle-sized ST (pair 23) and on the long arm of a middle-sized ST (pair 22) in M. aff. cotttoides and on the short arm of three middle-sized ST pairs, identified as pairs 9, 10 and 11, in P. bufonius. C-banding revealed a very small amount of constitutive heterochromatin in the chromosomes of all species, including the NORs. The occurrence of $2 n=54$ in all species of the family Pseudopimelodidae and its absence among species of the closely related Pimelodidae and Heptapteridae may be important in identifying Pseudopimelodidae species.
\end{abstract}

Key words: karyotype, chromosomes, C-banding, Ag-NOR, fish.

Received: November 14, 2007; Accepted: March 10, 2008.

The order Siluriformes (catfishes) has 3,093 species, divided into 36 families and 478 genera, and distributed worldwide, except for the coldest areas in the Northern and Southern hemispheres (Ferraris, 2007). Recent phylogenetic studies showed that the old family Pimelodidae comprised three monophyletic units: Pimelodidae, Heptapteridae and Pseudopimelodidae (Lundberg et al., 1991; de Pinna, 1998). According to Ferraris (2007), Pseudopimelodidae is composed of the genera Batrochoglanis (five species), Cephalosilurus (four species), Lophiosilurus (one species), Microglanis (14 species) and Pseudopimelodus (five species). A new genus and species, Cruciglanis pacifisi, has been recently described by Ortega-Lara and Lehmann (2006). This family is widely distributed in South America and is considered the least known family among the naked Neotropical freshwater catfishes (Shibatta, 2003). Currently, the only species to have their karyotypes reported are Microglanis garavelloi (cited as M. cottoides Vissotto et al., 1999a) and Pseudopimelodus mangurus (Martinez et al., 2004). The objective of the present study

Send correspondence to Claudio Oliveira. Departamento de Morfologia, Instituto de Biociências, Universidade Estadual Paulista, 18618-000 Botucatu, SP, Brazil. E-mail: claudio@ ibb.unesp.br. was to analyze the karyotypes of Cephalosilurus apurensis, Microglanis aff. cottoides and Pseudopimelodus bufonius.

The following specimens were karyotyped: one male specimen of Cephalosilurus apurensis from the Orinoco River, Caicara del Orinoco, Bolívar, Venezuela $\left(07^{\circ} 38^{\prime} 11.6^{\prime \prime} \mathrm{N}, 66^{\circ} 19^{\prime} 04.2^{\prime \prime} \mathrm{W}\right.$, LBP 3034); two males and four females of Microglanis aff. cotttoides from Ribeirão Cavalo Stream, Jaraguá do Sul, Santa Catarina, Brazil $\left(26^{\circ} 28,250^{\prime} \mathrm{S}, 49^{\circ} 10,958^{\prime} \mathrm{W}\right.$, LBP 731$)$ and two males and two females of Pseudopimelodus bufonius from the Amazon (aquarium trade, LBP 2345). The specimens were identified and deposited in the fish collection of the Laboratório de Biologia e Genética de Peixes (LBP), Departamento de Morfologia, Instituto de Biociências, Universidade Estadual Paulista, São Paulo, Brazil.

Mitotic chromosome preparations were obtained according to the technique described by Foresti et al. (1993). Nucleolar organizer regions (Ag-NORs) were revealed by the silver-staining method (Howell and Black, 1980) and C-banding was performed according to Sumner (1972). The chromosomes were classified according to their arm ratios as metacentrics (M), submetacentrics (SM), subtelocentrics (ST), and acrocentrics (A) (Levan et al., 1964). 
The three species analyzed possessed $2 \mathrm{n}=54$ chromosomes. Cephalosilurus apurensis had 6M, 28SM, 14ST and 6A (Figure 1a), Microglanis aff. cottoides presented 10M, 32SM, 10ST and 2A (Figure 2a) and Pseudopimelodus bufonius showed 12M, 30SM and 12ST (Figure 3a). A $2 n=54$ is characteristic for the family Pseudopimelodidae and the karyotypes of $C$. apurensis and $M$. aff. cottoides are similar to those observed in other species of the family, which typically have chromosomes of all morphological types, except for $M$. garavelloi and $P$. bufonius that do not have any acrocentric chromosome (Table 1).

The $2 \mathrm{n}=54$ present in Pseudopimelodidae contrasts with the modal $2 n=56$ found in most catfish families (Oliveira and Gosztonyi, 2000) and specially with the diploid numbers found among representatives of Heptapteridae and Pimelodidae, which are closely related to Pseudopimelodidae (Sullivan et al., 2006) (Table 1).

Pseudopimelodid species have single or multiple Ag-NORs (Table 1). Cephalosilurus apurensis showed a single pair of Ag-NORs on the short arms of a middle-sized ST pair, identified as pair 19 (Figure 1a). The remaining pseudopimelodid species analyzed also had a single Ag-NOR: Lophiosilurus alexandrii showed Ag-NORs on
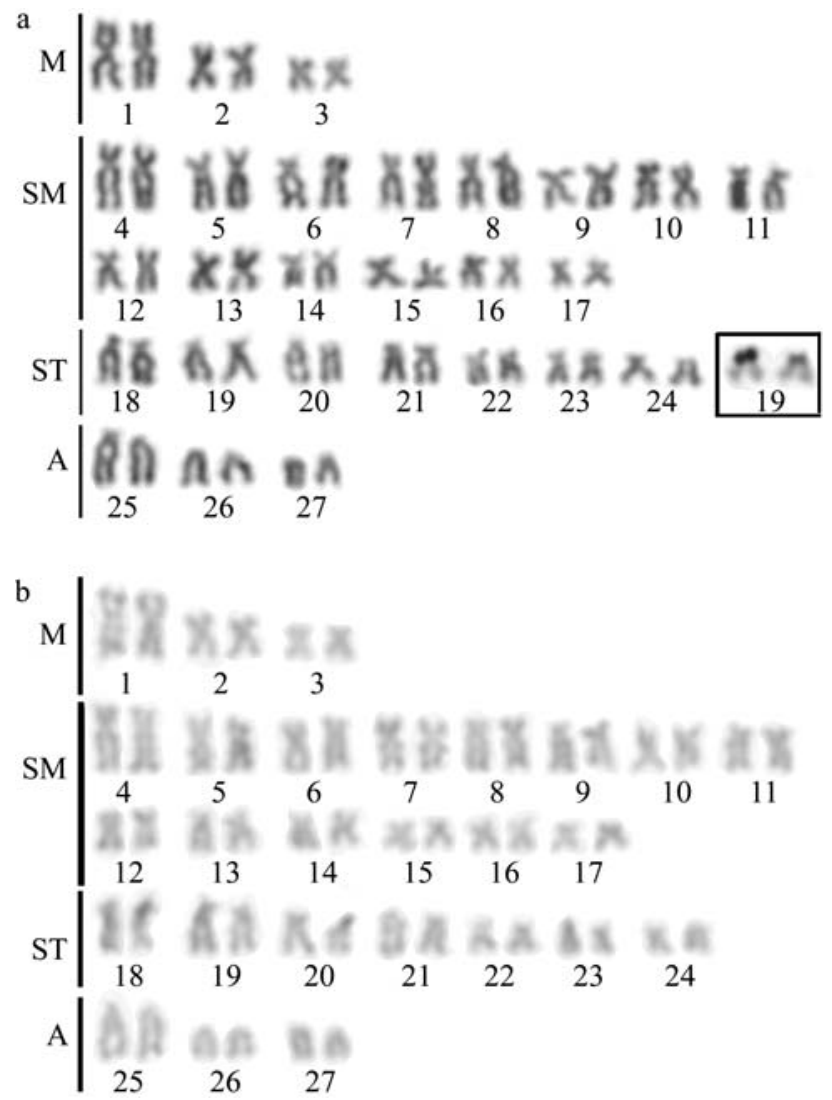

Figure 1 - Karyotype of Cephalosilurus apurensis $(2 \mathrm{n}=54)$ after: (a) conventional staining and (b) C-banding. In the inset, silver stained chromosomes showing the terminal Ag-NOR on the short arms of pair 19. the short arm of a SM (Marques, Garcia and Moreira Filho, personal communication); Microglanis garavelloi (Vissotto et al., 1999a) had Ag-NORs on the long arm of M; and Pseudopimelodus mangurus (Martinez et al., 2004) presented Ag-NORs on the short arm of SM/ST (Table 1). Single Ag-NORs were also identified in all species of Pimelodidae and all but one species of Heptapteridae (Table 1). This is also the most common condition in Siluriformes (Oliveira and Gosztonyi, 2000) and even in Teleostei (Klinkhardt, 1998). The Ag-NORs of M. aff. cotttoides were found on the short arm of a middle-sized ST pair,
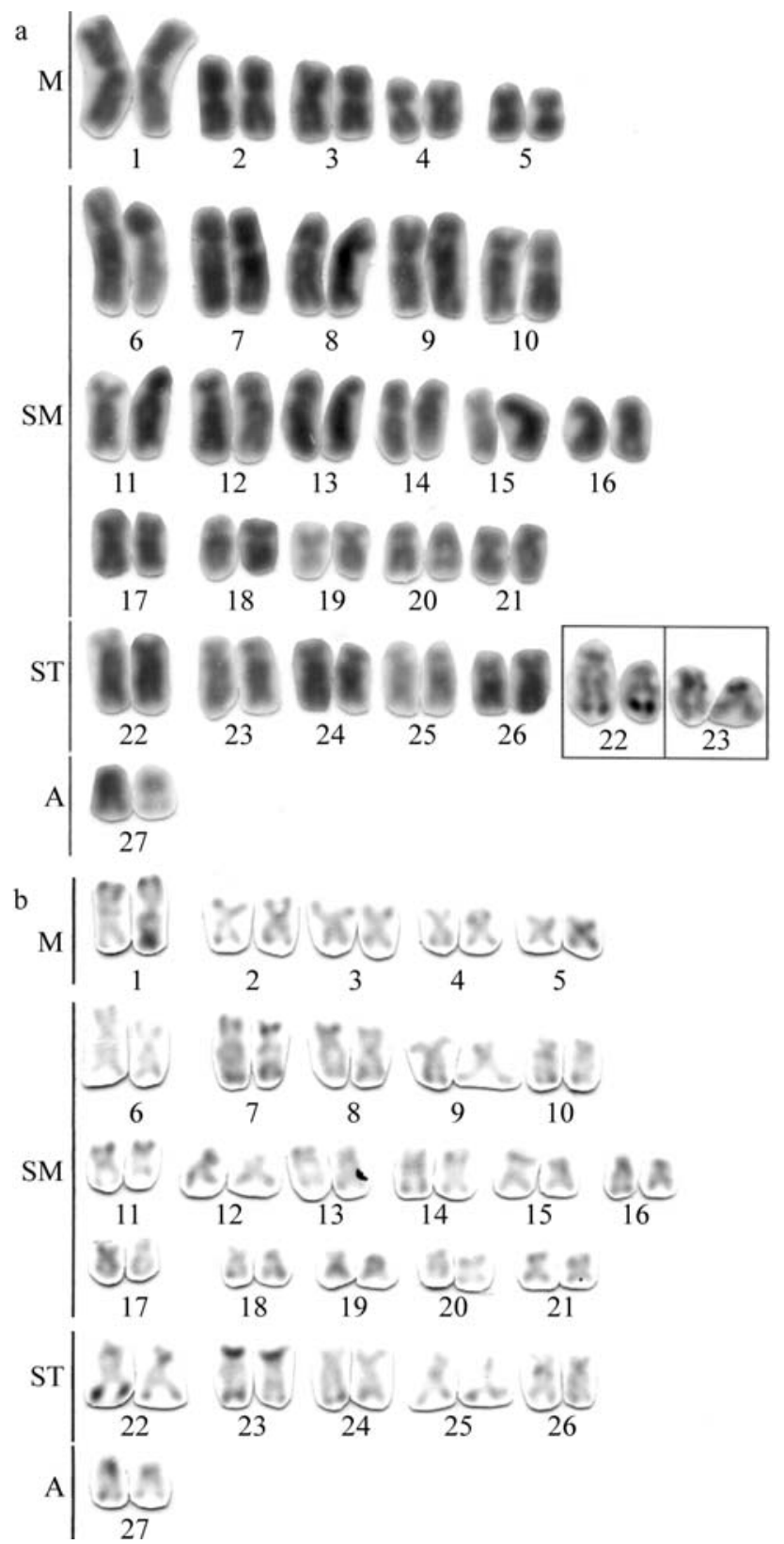

Figure 2 - Karyotype of Microglanis aff. cottoides $(2 \mathrm{n}=54)$ after: (a) conventional staining and (b) C-banding. In the inset, silver stained chromosomes showing the terminal Ag-NORs on the short arms of pair 23 and long arms of pair 22 . 
Table 1 - Cytogenetic data for Pseudopimelodidae, Heptapteridae and Pimelodidae.

\begin{tabular}{|c|c|c|c|c|c|}
\hline Family/species & Locality & $2 n$ & Karyotype & NOR & References \\
\hline \multicolumn{6}{|l|}{ Pseudopimelodidae } \\
\hline Cephalosilurus apurensis & $\begin{array}{l}\text { Orinoco River, Caicara del } \\
\text { Orinoco, Bolívar, Venezuela }\end{array}$ & 54 & $6 \mathrm{M}+28 \mathrm{SM}+14 \mathrm{ST}+6 \mathrm{~A}$ & 1 & Present study \\
\hline Lophiosilurus alexandrii & $\begin{array}{l}\text { Três Marias Reservoir, Minas Ge- } \\
\text { rais, Brazil }\end{array}$ & 54 & $54 \mathrm{M}, \mathrm{SM}, \mathrm{ST}, \mathrm{A}$ & 1 & $\begin{array}{l}\text { Marques, Garcia and Moreira } \\
\text { Filho (personal communication) }\end{array}$ \\
\hline Microglanis aff. cottoides & $\begin{array}{l}\text { Ribeirão Cavalo Stream, Jaraguá } \\
\text { do Sul, Santa Catarina, Brazil }\end{array}$ & 54 & $10 \mathrm{M}+32 \mathrm{SM}+10 \mathrm{ST}+2 \mathrm{~A}$ & 2 & Present study \\
\hline Microglanis garavelloi & $\begin{array}{l}\text { Araquá and Capivara Rivers, Botu- } \\
\text { catu, São Paulo, Brazil }\end{array}$ & 54 & $22 \mathrm{M}+20 \mathrm{SM}+12 \mathrm{ST}$ & 1 & Vissotto et al. (1999a) \\
\hline Pseudopimelodus bufonius & Amazon Basin & 54 & $12 \mathrm{M}+30 \mathrm{SM}+12 \mathrm{ST}$ & 3 & Present study \\
\hline Pseudopimelodus mangurus & $\begin{array}{l}\text { Mogi-Guaçu River, Pirassununga, } \\
\text { São Paulo, Brazil }\end{array}$ & 54 & $6 \mathrm{M}+26 \mathrm{SM}+12 \mathrm{ST}+10 \mathrm{~A}$ & 1 & Martinez et al. (2004) \\
\hline \multicolumn{6}{|l|}{ Heptapteridae } \\
\hline Pimelodella avanhandavae & Araquá River, São Paulo, Brazil & 46 & $20 \mathrm{M}+20 \mathrm{SM}+6 \mathrm{ST}$ & 1 & Vissotto et al. (1999a) \\
\hline Pimelodella aff. meeki & Couro do Boi River, Paraná, Brazil & 46 & $34 \mathrm{M}+12 \mathrm{ST}$ & 1 & $\begin{array}{l}\text { Dias and Giuliano-Caetano } \\
\text { (2002) }\end{array}$ \\
\hline Heptapterus longicauda & $\begin{array}{l}\text { Quinta Stream, Itatinga, São Pau- } \\
\text { lo, Brazil }\end{array}$ & 52 & $22 \mathrm{M}+26 \mathrm{SM}+4 \mathrm{ST}$ & 2 & Vissotto et al. (1999a) \\
\hline Pimelodella aff. avanhandavae & Tibagi River, Paraná, Brazil & 52 & $30 \mathrm{M}+22 \mathrm{SM}$ & 1 & Swarça et al. (2003a) \\
\hline Imparfinis cf. piperatus & $\begin{array}{l}\text { Juquiá River, Juquiá, São } \\
\text { Paulo, Brazil }\end{array}$ & 56 & $22 \mathrm{M}+26 \mathrm{SM}+4 \mathrm{ST}+4 \mathrm{~A}$ & 1 & Vissotto et al. (2001) \\
\hline Rhamdella microcephala & $\begin{array}{l}\text { Machado River, São João da Ma- } \\
\text { ta, Minas Gerais, Brazil }\end{array}$ & 56 & $18 \mathrm{M}+30 \mathrm{SM}+8 \mathrm{ST}, \mathrm{A}$ & 1 & Fonseca et al. (2003) \\
\hline Cetopsorhamdia iheringi & $\begin{array}{l}\text { Capivara River, Botucatu, São } \\
\text { Paulo, Brazil }\end{array}$ & 58 & $28 \mathrm{M}+24 \mathrm{SM}+6 \mathrm{ST}$ & 1 & Vissotto et al. (1999a) \\
\hline Imparfinis mirini & Quinta Stream, São Paulo, Brazil & 58 & $\mathrm{M} 24 \mathrm{M}+34 \mathrm{SM} / \mathrm{F} 23 \mathrm{M}+35 \mathrm{SM}$ & 1 & Vissotto et al. (1997) \\
\hline Imparfinis piperatus & $\begin{array}{l}\text { Araras River, Araras, São Pau- } \\
\text { lo, Brazil }\end{array}$ & 58 & $32 \mathrm{M}+26 \mathrm{SM}$ & 1 & Vissotto et al. (2001) \\
\hline Pimelodella kronei & Iporanga, São Paulo, Brazil & 58 & $54 \mathrm{M}, \mathrm{SM}+4 \mathrm{ST}$ & 1 & Almeida-Toledo et al. (1992) \\
\hline Pimelodella transitoria & Iporanga, São Paulo, Brazil & 58 & $54 \mathrm{M}, \mathrm{SM}+4 \mathrm{ST}$ & 1 & Almeida-Toledo et al. (1992) \\
\hline Rhamdia quelen & $\begin{array}{l}\text { Quadros Lagoon, Rio Grande do } \\
\text { Sul, Brazil }\end{array}$ & 58 & $52 \mathrm{M}, \mathrm{SM}, \mathrm{ST}+6 \mathrm{~A}$ & 1 & Hochberg and Erdtmann (1988) \\
\hline \multicolumn{6}{|l|}{ Pimelodidae } \\
\hline Calophysus macropterus & Negro River, Amazonas, Brazil & 50 & $22 \mathrm{M}+18 \mathrm{SM}+10 \mathrm{~A}$ & 1 & Ramirez-Gil et al. (1998) \\
\hline Pirinampus pinirampu & $\begin{array}{l}\text { Tibagi River, Sertaneja, Paraná, } \\
\text { Brazil }\end{array}$ & 50 & $26 \mathrm{M}+12 \mathrm{SM}+2 \mathrm{ST}+10 \mathrm{~A}$ & 1 & Swarça et al. (1999) \\
\hline Pseudoplatystoma fasciatum & Solimões River, Amazonas, Brazil & 56 & $18 \mathrm{M}+14 \mathrm{SM}+10 \mathrm{ST}+14 \mathrm{~A}$ & 1 & Fenocchio and Bertollo (1992) \\
\hline Pseudoplatystoma tigrinum & Solimões River, Amazonas, Brazil & 56 & $18 \mathrm{M}+16 \mathrm{SM}+8 \mathrm{ST}+14 \mathrm{~A}$ & 1 & Fenocchio and Bertollo (1992) \\
\hline Sorubim lima & Solimões River, Amazonas, Brazil & 56 & $18 \mathrm{M}+12 \mathrm{~S}+14 \mathrm{ST}+12 \mathrm{~A}$ & 1 & Fenocchio and Bertollo (1992) \\
\hline Bergiaria westermanni & $\begin{array}{l}\text { São Francisco River, Minas Ge- } \\
\text { rais, Brazil }\end{array}$ & 56 & $42 \mathrm{M}, \mathrm{SM}+14 \mathrm{ST}$ & 1 & Dias and Foresti (1993) \\
\hline Pimelodus heraldoi & Tibagi River, Paraná, Brazil & 56 & $22 \mathrm{M}+22 \mathrm{SM}+6 \mathrm{ST}+6 \mathrm{~A}$ & 1 & Souza et al. (2004) \\
\hline Pimelodus maculatus & $\begin{array}{l}\text { São Francisco River, Minas Ge- } \\
\text { rais, Brazil }\end{array}$ & 56 & $40 \mathrm{M}, \mathrm{SM}+16 \mathrm{ST}, \mathrm{A}$ & 1 & Dias and Foresti (1993) \\
\hline Pimelodus argenteus & $\begin{array}{l}\text { Paraguai River, Corumbá, Mato } \\
\text { Grosso do Sul, Brazil }\end{array}$ & 56 & $34 \mathrm{M}, \mathrm{SM}+22 \mathrm{ST}, \mathrm{A}$ & 1 & Souza et al. (2003) \\
\hline Pimelodus mysteriosus & $\begin{array}{l}\text { Paraguai River, Corumbá, Mato } \\
\text { Grosso do Sul, Brazi }\end{array}$ & 56 & $26 \mathrm{~m}+20 \mathrm{SM}+2 \mathrm{ST}+8 \mathrm{~A}$ & 1 & Souza et al. (2003) \\
\hline Pseudoplatystoma corruscans & Porto Rico, Paraná, Brazil & 56 & $18 \mathrm{M}+16 \mathrm{SM}+10 \mathrm{ST}+12 \mathrm{~A}$ & 1 & Martins-Santos et al. (1996) \\
\hline Hemisorubim platyrhynchos & Porto Rico, Paraná, Brazil & 56 & $22 \mathrm{M}+18 \mathrm{SM}+6 \mathrm{ST}+10 \mathrm{~A}$ & 1 & Martins-Santos et al. (1996) \\
\hline Zungaro zungaro & Foz do Iguaçu, Paraná, Brazil & 56 & $26 \mathrm{M}+10 \mathrm{SM}+6 \mathrm{ST}+14 \mathrm{~A}$ & 1 & Martins-Santos et al. (1996) \\
\hline Iheringichthys labrosus & $\begin{array}{l}\text { Jurumirim Reservoir, Itatinga, São } \\
\text { Paulo, Brazil }\end{array}$ & 56 & $22 \mathrm{M}+18 \mathrm{SM}+10 \mathrm{ST}+6 \mathrm{~A}$ & 1 & Vissotto et al. (1999b) \\
\hline Steindachneridion sp. & $\begin{array}{l}\text { Iguaçu River, Usina Salto Segre- } \\
\text { do, Paraná, Brazil }\end{array}$ & 56 & $20 \mathrm{M}+24 \mathrm{SM}+2 \mathrm{ST}+10 \mathrm{~A}$ & 1 & Swarça et al. (2003b) \\
\hline
\end{tabular}

$2 \mathrm{n}=$ diploid number; $\mathrm{M}=$ metacentrics; $\mathrm{SM}=$ submetacentrics; $\mathrm{ST}=$ subtelocentrics; $\mathrm{A}=$ acrocentrics; $\mathrm{NOR}=$ number of chromosome pairs with nucleolus organizer regions. 
a
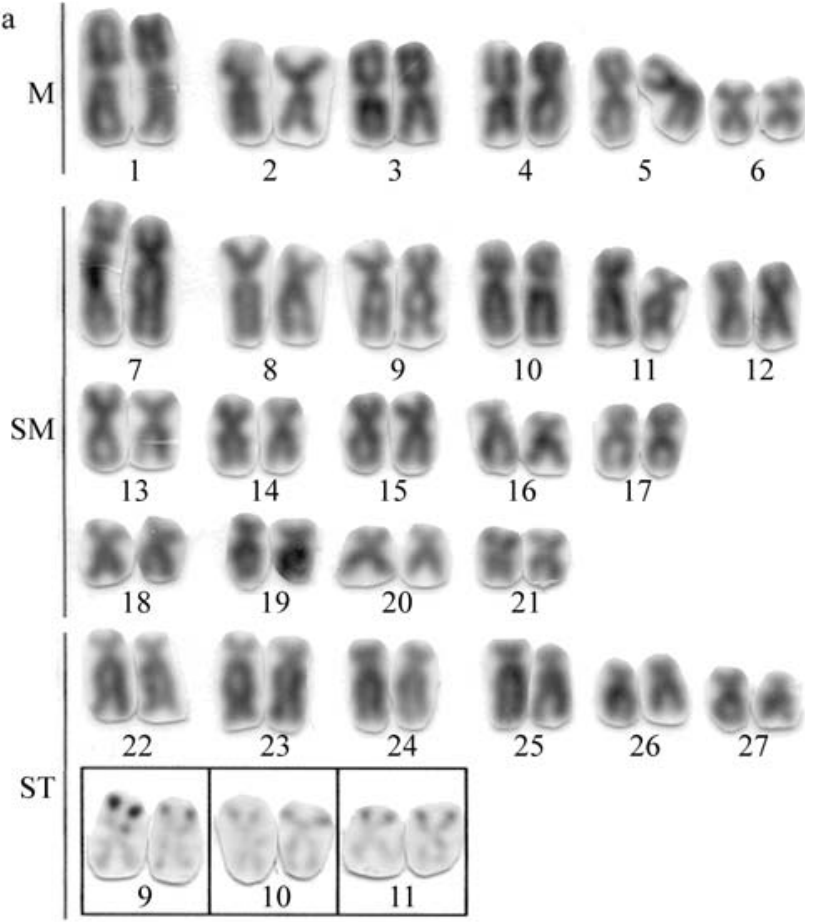

b

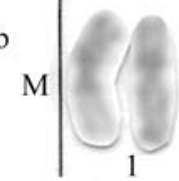

$\mid$

7

SM
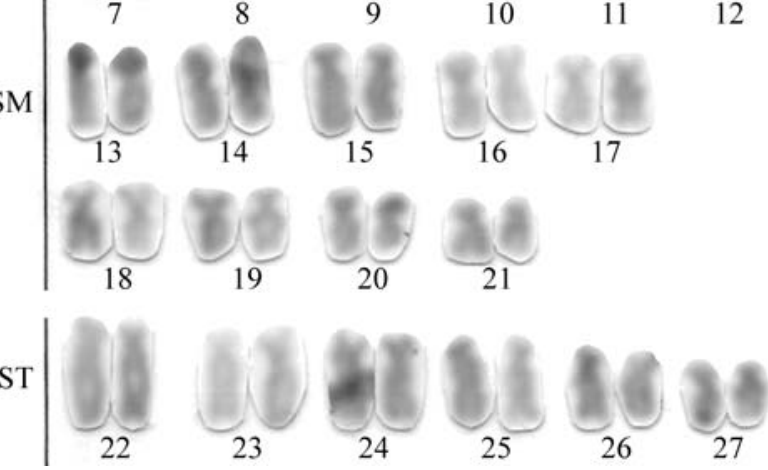

Figure 3 - Karyotype of Pseudopimelodus bufonius $(2 \mathrm{n}=54)$ after: (a) conventional staining and (b) C-banding. In the inset, silver stained chromosomes showing the terminal Ag-NORs on the long arms of pairs 9, 10 and 11 .

identified as pair 23, and on the long arm of another middle-sized ST pair, identified as pair 22 (Figure 2a). The Ag-NORs of $P$. bufonius occurred on the short arm of three middle-sized ST pairs, identified as pairs 9, 10 and 11 (Figure 3a). Multiple Ag-NORs were identified in one species of Heptapteridae (Vissotto et al., 1999a) and were not found among Pimelodidae (Table 1). The number and position of NORs are species-specific and do not seem to follow any pattern during karyotypic evolution.
C-banding showed the occurrence of a small amount of constitutive heterochromatin in the chromosomes of the three species (Figures 1b, 2b, 3b). In Cephalosilurus apurensis, positive C-banded segments were observed on the short arms of the largest ST pair (pair 19) and in the Ag-NORs. In Pseudopimelodus bufonius, C-banding evidenced segments on the short arms of the six larger SM pairs (pairs 9, 10, 11, 12, 13 and 14) and in Microglanis aff. cottoides, C-banding revealed positive segments on the short arms of one large ST pair (pair 23) and on the long arms of several ST pairs. The small amount of heterochromatic segments in the chromosomes of $P$. bufonius, $M$. aff. cottoides, and C. apurensis, as well as in other representatives of the family Pseudopimelodidae, P. mangurus (Martinez et al., 2004), and M. garavelloi (Vissotto et al., 1999a), suggests that this may be a characteristic of this catfish family. The occurrence of a very small amount of C-banded positive segments reported herein resembles the data reported for many teleost species, including siluriforms (Gold et al., 1990).

The presence of $2 \mathrm{n}=54$ chromosomes may be an important characteristic to differentiate Pseudopimelodidae species from species of Heptapteridae and Pimelodidae. Further analysis of additional Pseudopimelodidae species with different staining techniques will provide important information for a better understanding of the chromosome evolution in the group and will help to confirm the conservative nature of the diploid number in this fish family.

\section{Acknowledgments}

The authors are grateful to O.A. Shibatta for assistance in identifying the specimens and to R. Devidé for technical assistance. This study was supported by the Fundação de Amparo à Pesquisa do Estado de São Paulo (FAPESP), Conselho Nacional de Investigação Científica (CNPq) and Coordenadoria de Apoio à Pós-Graduação e Pesquisa (CAPES).

\section{References}

Almeida-Toledo LF, Foresti F, Trajano E and Toledo Filho SA (1992) Cytogenetic analysis of the Brazilian blind catfish Pimelodella kronei and its presumed ancestor, $P$. transitoria. Caryologia 45:255-262.

de Pinna MCC (1998) Phylogenetic relationships of Neotropical Siluriformes (Teleostei, Ostariophysi): Historical overview and synthesis of hypotheses. In: Malabarba LR, Reis RE, Vari RP, Lucena ZMS and Lucena CAS (eds) Phylogeny and Classification of Neotropical Fishes. Edipucrs, Porto Alegre, pp 279-330.

Dias AL and Foresti F (1993) Cytogenetic studies on fishes of the family Pimelodidae (Siluroidei). Rev Brasil Genet 16:585600.

Dias AL and Giuliano-Caetano L (2002) Citogenética de alguns grupos de peixes da bacia do rio Tibagi. In: Medri ME, Bianchini E, Shibatta OA and Pimenta JA (eds) A Bacia do 
Rio Tibagi. Editora da Universidade Estadual de Londrina, Londrina, pp 473-529.

Fenocchio AS and Bertollo LAC (1992) Karyotype similarities among Pimelodidae (Pisces, Siluriformes) from the Brazilian Amazon region. Cytobios 69:41-46.

Ferraris CJ (2007) Checklist of catfishes, recent and fossil (Osteichthyes, Siluriformes), and catalogue of siluriform primary types. Zootaxa 1418:1-628.

Fonseca YM, Oliveira C, Foresti F and Maistro EL (2003) First cytogenetic description of the species Rhamdella microcephala (Pisces, Hepapteridae). Cytologia 68:31-34.

Foresti F, Oliveira C and Almeida-Toledo LF (1993) A method for chromosome preparations from large specimens of fishes using in vitro short treatment with colchicine. Experientia 49:810-813.

Gold JR, Li YC, Shipley NS and Powers PK (1990) Improved methods for working with fish chromosomes with a review of metaphase chromosome banding. J Fish Biol 37:563-575.

Hochberg VBM and Erdtmann B (1988) Cytogenetical and morphological considerations on Rhamdia quelen (Pisces, Pimelodidae) - The occurrence of B chromosomes and polymorphic NOR regions. Rev Brasil Genet 11:563-576.

Howell WM and Black DA (1980) Controlled silver-staining of nucleolus organizer regions with a protective colloidal developer: A 1-step method. Experientia 36:1014-1015.

Klinkhardt M (1998) Some aspects of karyoevolution in fishes. Anim Res Dev 47:7-36.

Levan A, Fredga K and Sandberg AA (1964) Nomenclature for centromeric position on chromosomes. Hereditas 52:201220.

Lundberg JG, Mago-Leccia F and Nass P (1991) Exallodontus aguanai, a new genus and species of Pimelodidae (Pisces, Siluriformes) from deep river channels of South America, and delimitation of the subfamily Pimelodinae. Proc Biol Soc Washington 104:840-869.

Martinez ERM, Oliveira C and Foresti F (2004) Cytogenetic analyses of Pseudopimelodus mangurus (Teleostei, Siluriformes, Pseudopimelodidae). Cytologia 69:419-424.

Martins-Santos IC, Julio Jr. HF and Burin I (1996) Karyotypic studies of four species of the Sorubiminae subfamily (Pisces, Siuriformes). Caryologia 49:73-80.

Oliveira C and Gosztonyi AE (2000) A cytogenetic study of Diplomystes mesembrinus (Teleostei, Siluriformes, Diplomystidae) with a discussion of chromosome evolution in siluriforms. Caryologia 53:31-37.

Ortega-Lara A and Lehmann PA (2006) Cruciglanis, a new genus of Pseudopimelodid catfish (Ostariophysi, Siluriformes) with description of a new species from the Colombian $\mathrm{Pa}-$ cific coast. Neotrop Ichthyol 4:147-156.
Ramirez-Gil H, Feldberg E, Almeida-Val VMF and Val AL (1998) Karyological, biochemical, and physiological aspects of Callophysus macropterus (Siluriformes, Pimelodidae) from the Solimões and Negro rivers (Central Amazon). Braz J Med Biol Res 31:1449-1458.

Shibatta OA (2003) Family Pseudopimelodidae. In: Reis RE, Kullander SO and Ferraris Jr. CJ (eds) Checklist of the Freshwater Fishes of South America. Edipucrs, Porto Alegre, pp 401-405.

Souza L, Giuliano-Caetano L and Dias AL (2003) Karyotypic study of three species of Pimelodus (Pisces, Pimelodidae) from the Paraguai River basin. Cytologia 68:345-350.

Souza L, Giuliano-Caetano L and Dias AL (2004) Banding chromosome pattern of two species of Pimelodus (Siluriformes, Pimelodidae) from the Parana River Basin of Brazil. Folia Biol 52:165-169.

Sullivan JP, Lundberg JG and Hardman M (2006) A phylogenetic analysis of the major groups of catfishes (Teleostei, Siluriformes) using rag1 and rag2 nuclear gene sequences. Mol Phylogenet Evol 41:636-662.

Sumner AT (1972) A simple technique for demonstrating centromeric heterochromatin. Exp Cell Res 75:304-306.

Swarça AC, Fenocchio AS, Cestari MM and Dias AL (2003b) Analysis of heterochromatin by combination of C-banding and CMA3 and DAPI staining in two fish species (Pimelodidae, Siluriformes). Genetica 119:87-92.

Swarça AC, Giulinao-Caetano L and Dias AL (1999) Cytogenetic characterization through chromosomic banding of Pirinampus pirinampu (Pisces, Pimelodiae) from the Tibagi river basin PR/Brazil. Caryologia 52:31-35.

Swarça AC, Vidotto AP and Dias AL (2003a) Cytogenetic characterization of Pimelodella aff. avanhandavae (Siluriformes, Pimelodidae) from Tibagi river (Paraná State, Brazil). Caryologia 56:421-425.

Vissotto PC, Foresti F and Oliveira C (1997) A ZZ/ZW sex chromosome system in Imparfinis mirini (Pisces, Siluriformes). Cytologia 62:61-66.

Vissotto PC, Foresti F and Oliveira C (1999a) Karyotype description of five species of Pimelodidae (Teleostei, Siluriformes). Chromosome Sci 3:1-7.

Vissotto PC, Foresti F and Oliveira C (1999b) Supernumerary chromosomes in two species of the family Pimelodidae (Teleostei, Siluriformes). Chromosome Sci 3:9-13.

Vissotto PC, Foresti F and Oliveira C (2001) Karyotypic characterization of two species of the genus Imparfinis (Teleostei, Siluriformes, Heptapteridae). Chromosome Sci 5:97-103.

Associate Editor: Yatiyo Yonenaga-Yassuda

License information: This is an open-access article distributed under the terms of the Creative Commons Attribution License, which permits unrestricted use, distribution, and reproduction in any medium, provided the original work is properly cited. 